\title{
Intersecting Inequalities: The Representation of Religious, Gender, and Sexual Identities in the Life of Pelagia
}

\author{
MARIANA BODNARUK ${ }^{*}$
}

Repentant harlots who became trans saints presented Byzantine hagiographers with a challenge. Thought to exhibit a lack of self-control and the excessive sexuality, associated with women, and sex workers in particular, - a subject of great concern for monastic authors - how could members of this stigmatized group achieve the standards of Christian piety, let alone saintly behavior? In portraying its fictional protagonist as an exemplum of masculine virtues in the context of nascent Palestinian monasticism, the anonymous Life of Pelagia highlights the non-binariness of social identities in early Byzantium, unsettling fixed gender categorization. Conceiving of a trans figure of an ascetic subverting conventional binaries, the Life creates a model for incorporating non-conforming masculinities of Byzantine society within the normative hagiographic genre.

Keywords: trans saints, Pelagia/Pelagios, masculinity, non-binary, Byzantium, hagiography, sanctity, exemplarity, religion and gender

Since the fifth century, a woman turning into a male solitary or cenobite has haunted Byzantine hagiography. In a recurrent story, the female protagonist who took on the monastic habit and was made unfeminine by fasting, lives as a recluse or a monk passing for a male. The figure is assumed to be a man, but, having a delicate voice, beardless face and no need for shaving, is ascribed the gender identity of a male eunuch. The reformed sex worker Pelagia is the earliest of late antique trans saints. ${ }^{1}$ The Life of Pelagia is dated to the fifth century. ${ }^{2}$ Although originally written in Greek, the earliest, pre-metaphrastic vita has come down to us in a seventh-century Syriac version. ${ }^{3}$ This

\footnotetext{
* Mariana Bodnaruk, Pontica Magna Postdoctoral Fellow, New Europe College, Institute for Advanced Study, Str. Plantelor 21, 023971, Bucharest, mbodnaruk@nec.ro.

${ }^{1}$ For a discussion on the spiritual meaning of such stories in Eastern ascetic literature see: the chapter "God's Holy Harlots: The Redemptive Lives of Pelagia of Antioch and Mary of Egypt," in Lynda L. Coon, Sacred Fictions: Holy Women and Hagiography in Late Antiquity (Philadelphia: University of Pennsylvania Press, 1997), 71-94.

2 Pierre Petitmengin, ed., Pélagie la pénitente. Métamorphoses d’une légende (Paris: Études Augustiniennes, 1981), 14-15.

3 Sebastian O. Brock and Susan Ashbrook Harvey, trans., Holy Women of the Syrian Orient (Berkeley: University of California Press, 1987), 41.
}

RES 13 (3/2021), p. 419-436 
form of sanctity remained firmly in fashion in Byzantium until the ninth century, but the trans saints enjoyed immense popularity in the Greekspeaking Mediterranean throughout the next three centuries. From the ninth to the eleventh century, these saints' lives saw a revival as evidenced by the increase in the manuscript copying of earlier stories as well as the production of new vitae. ${ }^{4}$ The trans saints were aspirational models of gender ascent, from female to male, showing thus the salvific path for all genders, despite the specific church and state prohibitions against practices followed by these fictional figures. ${ }^{5}$

The text presents the protagonist before and after becoming a monastic. In the first part of the Life Pelagia is depicted as a worldly woman, contrasted to Pelagios' portrayal as a male ascetic in the second part. I propose to take up the issue of trans saints to explore how, in the specific religious context, gender and sexuality are conceptualized as a point of conflict. I explore the construct of gender fluidity and ambivalence in the vita in order to understand the range of late ancient gender and gendered performances, including the gendering of virtue, spiritual progress, and asceticism as integral to the construction of early Christian identity. I begin with the critical historiographical reading, examining theoretical assumptions of feminist scholars and, most recently, researchers informed by trans theory. I then proceed with a discussion of how the shaping of religious identity clearly intersects with gender and sexuality. The Life of Pelagia will be considered not only as "symbolic literature," which is of use primarily in revealing the religious perspectives and ethical ideals prevalent in the era when it was written and read, but also as a historical source. I argue that the Life of Pelagia put in its historical context is not merely a fictional text with gendered intertexts, or literary motifs, but a work with a clear religious aim that mediates Byzantine social identities.

\section{Historiography of "transvestite saints"}

What makes the feminist theory significant is that it brings to the forefront those forms of agency and identity that have remained at the periphery of previous historiographical considerations, in particular, gender and sexuality.

\footnotetext{
${ }^{4}$ Stephen J. Davis, "Crossed Texts, Crossed Sex: Intertextuality and Gender in Early Christian Legends of Holy Women Disguised as Men," Journal of Early Christian Studies 10, no. 1 (2002): 8.

${ }^{5}$ Council of Gangra, canons 13 and 17: "The Council of Gangra," in Nicene and Post-Nicene Fathers, Second Series, vol. 14, eds. Philip Schaff and Henry Wace (Buffalo, NY: Christian Literature Publishing, 1900), 97 and 99; Codex Theodosianus 16.2.27: The Theodosian Code and Novels and the Sirmondian Constitutions, trans. Clyde Pharr (Princeton: Princeton University Press, 1952), 445.
} 
Therefore, a critical examination of feminist scholarship, which has sought to reinstate women's agency into a reading of early hagiographies, is needed. However, recent historiography based on trans theory has challenged the conventional view of these so-called "transvestite" saints as both female and binary ones. It equally aims to excavate the trans and queer identities, recovering narratives of trans and gender-fluid persons across late antique and Byzantine literature. Thoroughgoing theoretical reflection would be especially important going forward.

Since its inception, feminist scholarship on late antique trans saints has revolved around two conflicting interpretations of the lives of queer ascetics. Hagiography critics who take up the question of female saints focus on the relationship between social domination and resistance. Feminist readings therefore at once establish the principal role of gender as both a point of oppression and a fount of resistance. They hold that, in Pelagia's case, the woman was able to act in some way and assert her specifically female piety and religiosity, in what they see as an instance of resistance to the broader patriarchal culture. Essentializing women saints as either victims of patriarchal violence or agents of resistance, feminist critics are caught in a double bind.

Marie Decourt was one of the first scholars to emphasize that the theme of the trans saint had probably arisen in the atmosphere of early Christian asceticism. Literary representations of these saints vary between the poles of an ascetic renunciation and penitence of harlots and that of the passion and martyrdom of virgins. Asceticism and martyrdom were the two most spectacular and celebrated practices of bodily piety in early Christianity. Decourt interprets Pelagia's act of assuming male attire as her abolition of femaleness and aspiration to ideal androgyny for the purpose of a spiritual advance. ${ }^{6}$ According to this reading, Pelagia takes on male garb to purge herself of feminine wiles and weaknesses and to flee her feminine condition, as women were repeatedly encouraged to become masculine to achieve spiritual progress, with masculine behaviour presented as an ideal of pious behavior. In Gillian Clark's words, "[f]emaleness as such was still a cause of shame, even if the solitary woman took refuge in desert."

For Evelyn Patlagean, the representation of the women saints was pronouncedly an image of female independence and autonomy. ${ }^{8}$ She views

\footnotetext{
${ }^{6}$ Marie Delcourt, Hermaphrodite: Myths and Rites of the Bisexual Figure in Classical Antiquity (London: Studio Books, 1961), 101.

${ }^{7}$ Gillian Clark, Women in Late Antiquity: Pagan and Christian Lifestyles (Oxford: Clarendon, 1993), 129.

${ }^{8}$ Evelyne Patlagean, "L'histoire de la femme déguisée en moine et l'évolution de la sainteté féminine à Byzance,” Studi Medievali 3, no. 17 (1976): 597-623.
} 
Pelagia, throughout the Life, unambiguously as a woman, albeit in "disguise." When, after the ninth century, the character of the "disguised" woman disappeared, superseded by a new model of female holiness, the exemplary value of this paradoxical figure was erased. ${ }^{9}$ She sees Pelagia as an embodiment of an anti-patriarchal example of a woman with a man's autonomy.

Furthermore, according to Laila Abdalla, asceticism permitted the woman eschewing the physical body to liberate a "feminine" spirit that, albeit female, is nonetheless rational. In her words, "[t]he saint's fictionality allows to enact a form of feminist religiosity that is rational but not masculine." 10 In her decisiveness and determination, Pelagia subverts efforts to assign her a "higher" status. Early ecclesiastical authors relieved the female from her "classical and Judaic subjugation," yet understood her as inherently less able than the male as a "woman indicated humanity's postlapsarian condition." 11 Hagiography as fiction depicts, although in a veiled manner, the celebration of the "temporal woman" as woman against an authoritative background: " $[t]$ he legends challenge the patristic determination of female asceticism as the divestment of feminine affectivity and the assumption of the armor of masculine intellectuality." 12 Hagiographic imagery thereby exposes tensions between the exaltation of the feminine gender dear to God and that which is negated by church authorities of the period with all its attendant restrictions. For Abdalla, "[f]olklore engages with authority to contend covertly that women serve and venerate God by fulfilling rather than rejecting their inherent qualities." 13

Pelagia reverses her lifestyle when, following Abdalla, she "masks" her gender. She renounces the symbols of sinful femininity (gowns and pearls) for the sake of an austere masculinity (hair shirt and male attire). The hermit-eunuch Pelagios effectively inverts the character of the materialist-sex worker Pelagia. While Satan urges her to retain the life of female fleshliness, her femininity now repudiates the sin. But if a representative of the elect church authority, in spite of his masculinity, is as guilty of the propensity to $\sin$ as the female entertainer, the rational piety purportedly indicated by Pelagia's "disguise" is thus negated by her own Life. Abdalla concludes that Pelagia's legend "reassesses further the illusory significance of male attire: just

\footnotetext{
${ }^{9}$ Ibidem, 597.

${ }^{10}$ Laila Abdalla, "Theology and Culture: Masculinizing the Woman," in Varieties of Devotion in the Middle Ages and Renaissance, ed. Susan C. Karant-Nunn (Turnhout: Brepols, 2003), 21.

${ }^{11}$ Ibidem, 18.

${ }^{12}$ Ibidem.

${ }^{13}$ Ibidem.
} 
as masculinity is deprived of ontological superiority, so too femininity is not delineated as naturally inferior." 14

Patricia Cox Miller has argued that the figure of the "harlot-saint" as a "grotesquerie" - not a coherent construct - is the "most acute expression of the problematic quality of early Christian attempts to construct a representation of female holiness." ${ }^{15}$ Cox Miller states that as autonomous lovers, whose agency is connected with sexuality, courtesans, like Pelagia, are "free agents and as such they disrupt male norms of subjectivity," "cross forbidden boundaries between domestic, private, female-gendered space and public, male-gendered space." ${ }^{16}$ According to her, "even after their conversions, they continue to occupy positions of agency, not only by switching teaching and priestly roles with their male interlocutors but also by practicing their spirituality in solitude, apart from male ecclesiastical structures." ${ }^{17}$

For Stavroula Constantinou, Pelagia (and later Theodora of Alexandria) decides to cross-dress and to enter holy orders after being forced by a male authority to interrupt a life of $\sin .{ }^{18}$ In the case of Pelagia and Theodora, "the monk's robe also functions as a symbol of the abandonment of their sinful female selves." ${ }^{19}$ For the cross-dressers whose femininity remains secret until their death (Pelagia, Theodora, Mary, Euphrosyne, and Marina), their "life behind the mask" is never exposed in their lives. Constantinou concurs that the monks in the hagiographies of cross-dressers die as men (Pelagia, Theodora, Mary, and Euphrosyne), but points out that it is the cross-dresser's dead body that becomes the means through which her femininity is revealed. In Kristi Upson-Saia's words, "[t]hrough several narrative techniques, the lives attempted to diffuse the dress practice's challenge to the conventional gender binary by inscribing and naturalizing femininity onto the ascetic's hidden body." ${ }^{20}$

\footnotetext{
${ }^{14}$ Ibidem, 30.

${ }^{15}$ Patricia Cox Miller, "Is There a Harlot in This Text?: Hagiography and the Grotesque," in The Cultural Turn in Late Ancient Studies: Gender, Asceticism, and Historiography, eds. Dale B. Martin and Patricia Cox Miller (Durham, NC: Duke University Press, 2005), 91.

${ }^{16}$ Ibidem, 97.

${ }^{17}$ Ibidem.

${ }^{18}$ Stavroula Constantinou, Female Corporeal Performances: Reading the Body in Byzantine Passions and Lives of Holy Women (Uppsala: Uppsala University, 2005), 65-66, 82.

${ }^{19}$ Idem, "Holy Actors and Actresses: Fools and Cross-Dressers as the Protagonists of Saints' Lives," in The Ashgate Research Companion to Byzantine Hagiography, vol. 2, ed. Stephanos Efthymiadis (Burlington, VT: Ashgate, 2014), 349.

${ }^{20}$ Kristi Upson-Saia, "Gender and Narrative Performance in Early Christian Cross-Dressing Saints' Lives,” Studia Patristica 45 (2010): 43.
} 
While the emphasis in the previous decades was on assimilation of masculinity and masculine piety by female saints, contemporary feminist scholars, such as Crystal L. Lubinsky, focus on how forms of women's agency arose in a religious and, more specifically, monastic context, rejecting masculinization of protagonists of the vitae as merely superficial and instrumental. ${ }^{21}$ For Lubinsky, "transvestism" functions as a textual device that permits the hagiographer to rationalize how the retired sex worker traveled unaccompanied to the Holy Land. She writes that the act of taking on male "disguise" enabled Pelagia to journey and to live as a monk without being noticed or observed. She considers it as merely an explanatory tool for it was safer for a woman to dress as a man to pursue a solitary life in the desert unhindered. She emphasizes the ability of hagiography to instruct/chastise mixed audiences, contextualizing celebration of a holy womanhood within an acceptable gendered language, which, for her, "seems to support a belief in the spiritual potential of women." ${ }^{22}$ Lubinsky concludes that even the earliest Pelagia's hagiography did not intend to develop a detailed "layered masculinity" around this character, and "transvestism" is used in the latter half of her Life "with no consequence or observable necessity."

Although it is wholly praiseworthy to use the feminist theoretical framework in setting out to recover the agency of women in these texts, it is only then possible to recognize women's active role when it is not transformed into its opposite. However, what these scholars portray are the female protagonists utilizing "cross-dressing" solely as a practical strategy ${ }^{23}$ that permits them to overcome obstacles to pursuing an ascetic life, that is, women making the best of the choices available to them in society. For feminist critics, Pelagia and others are striving to exercise their female piety in conditions that are intrinsically hostile to them. Yet, these women act so perceiving their circumstances as a given, not by attempting to overcome the constraints. If one is to view their actions as emblematic of women's agency, then there ceases to be any distinction between patriarchal ideology and resistance towards it. There is thus a substantial gap between what the critics claim to demonstrate and what they actually assert in their works. In other words, feminist analysis presents a reading in which an act of acquiescence

\footnotetext{
${ }^{21}$ Crystal L. Lubinsky, Removing Masculine Layers to Reveal a Holy Womanhood: The Female Transvestite Monks of Late Antique Eastern Christianity (Turnhout: Brepols, 2013), 15-40.

22 Ibidem, 19.

${ }^{23}$ Caroline Walker Bynum, Holy Feast and Holy Fast: The Religious Significance of Food to Medieval Women (Berkeley: University of California Press, 1987), 291: views "cross-dressing" as a "practical device" ensuring safe conduct and allowing women to fill social roles assigned exclusively to men.
} 
is shown as a female struggle. But this amounts to an effacement of women's agency, rather than to its recovery.

In the early 2020s, hagiography critics equipped with trans theory, embarked on a mission to bring to light a history of transgender and gender-variant individuals in late antiquity. They discard the labels of "transvestite" or "cross-dressing" saints as pejorative and problematic. Thus, Roland Betancourt argues that these saints should be understood as transgender by contextualizing the narratives within the social, religious, and medical practices of the period that framed their lives, where "transgender" is used as an umbrella term applicable to a variety of gender-variant practices and individuals. ${ }^{24}$ Pelagia does not temporarily choose "cross-dressing" as a form of expression; for the last three years of her life until her death she lives full-time as the "opposite" gender. These scholars, while discussing literary figures like Pelagia, similarly to feminist critics, aim to reveal an agency not only in the texts, but also as "real and viable possibilities for lived subjectivities" 25 in the early Byzantine world as demonstrated by the historicity of both prohibitions found in church canons and imperial legislation as well as Byzantine medical texts and practices.

In Betancourt's reading of the Life, despite his female sex assigned at birth, Pelagios effectively transitioned. For him, Pelagia is already only "passing as a cis woman" long before her acceptance to the lavra in Palestine: "Pelagius's life as a sex worker was, by all social accounts, masculine." ${ }^{26}$ According to Betancourt, "in the author's narrative arc, the bodily transformation of Pelagius only completed a path toward masculine gender expression that he had already begun well before his baptism and asceticism." ${ }^{27}$ For the scholar, the "female-passing" Pelagios is introduced early into the narrative as a highly feminized sex worker, wearing his scarf in the manner of a man: "[ $t$ ]hese two appearances - as sex worker and ascetic - though apparently in contradiction to one another, in reality, make legible the outward gender expression of Pelagius's identity and are united by masculinity." ${ }^{28}$ Betancourt concludes that the narrative hints that "a monk's gender identity was not solely the result of his asceticism but was to some degree the cause of it - even if that subtle implication would have been legible to a Christian

\footnotetext{
${ }^{24}$ Roland Betancourt, Byzantine Intersectionality: Sexuality, Gender, and Race in the Middle Ages (Princeton: Princeton University Press, 2020), 90.

${ }^{25}$ Ibidem, 91.

${ }^{26}$ Ibidem, 102.

${ }^{27}$ Ibidem, 106

${ }^{28}$ Ibidem, 105.
} 
reader only as an indicator of the sex worker's aberrant ways." ${ }^{29}$ Overall, in Betancourt's words, the saints' lives show that "the asceticism of these women might have been practiced to intentionally transform their female bodies into more masculine forms." ${ }^{30}$ Lastly, he asks the reader to respect these figures "as men." It is less a history of trans people in late antiquity written from the perspective of a contemporary conjuncture than that of Byzantine imagining that represents experiences of marginalized social identities.

Trans theory aims at recuperating a multiplicity of early Byzantine social identities as lived phenomena beyond their highly mediated representation in text and iconography. Saints' lives allow us to access not only the Byzantine imagination. These narratives offer models of emulation, but their staging of multiple social identities also depicts Byzantine society as regulating the lives of individuals. While one cannot deny the existence of people in Byzantium who in modern-day vocabulary would identify as trans, the possibility to project this term back onto the past in such an apodictic way is contentious. Although these texts are largely fictional, they were neither created nor read as such by their Christian audiences in Byzantium and elsewhere. In their original contexts of production as well as later reception, these narratives were regarded as those relating true stories. It is in this capacity that they carried value for believers and aimed at constructing a religious self by identification with saintly heroes. ${ }^{31}$

\section{Intersectionality, hagiography, and Byzantine society}

In what follows, I historicize late antique social identities as mediated by the literary genre of hagiography on the intersection of religion, gender, and sexuality. The tales of trans saints provide an illustration of how these identities intersect. As a man Pelagios is depicted as living out in a male monastic community only for the last three years of his life. However, Betancourt claims that Pelagios, who had been assigned female at birth, began his gender transition - from feminine inferiority to masculine superiority - already as a sex worker. ${ }^{32}$ As such, the protagonist leaves the head uncovered in public and wears a scarf thrown round the shoulders as a man:

The bishops as they sat there were amazed at her and her clothes, as well as the splendor of her cortege, and the fact that she went by

\footnotetext{
${ }^{29}$ Ibidem, 106.

${ }^{30}$ Ibidem, 113.

${ }^{31}$ Stratis Papaioannou, ed. and trans., Christian Novels from the Menologion of Symeon Metaphrastes (Cambridge, MA: Harvard University Press, 2017), xviii.

32 Betancourt, Byzantine Intersectionality, 101.
} 
with her head uncovered, with a scarf thrown round her shoulders in a shameless fashion, as though she were a man; indeed in her haughty impudence her garb was not very different from a man's, apart from her makeup, and the fact that her skin was as dazzling as snow. To put it briefly, her appearance incited everyone who set eyes on her to fall in love with her. When the holy bishops saw her, they averted their eyes from her, as though she was some sinful object. ${ }^{33}$

However, as exposed and unbound hair was frequently associated with sexually loose women in the late antique Mediterranean, it would be an apt detail to note in portraying a female sex worker. Pelagia does not deliberately masculinize her gender expression and remove all forms of feminine ornamentation except for her make up. Betancourt concedes that the figure of the sex worker is allowed an ostentatious manifestation of dress and an exuberant femininity. ${ }^{34}$ The narrator recounts how wealthy Pelagia puts on a spectacle of a flamboyant urban procession displaying a markedly feminine behavior. The reader further learns that all her "wealth has been amassed as the result of the sin of prostitution." ${ }^{35}$ She clearly did not lure her rich male lovers as a man. It is not a story of same-sex desires, behaviors, or sexual subcultures among men in Byzantium. In contrast, Pelagia clearly perceives herself as a woman.

It is in fact her femininity that is tied to excessive pleasure and sexuality. In the Life, Pelagia is slut-shamed for her daring appearance and garb as a sex worker. ${ }^{36}$ She is both desired and objectified as a woman. We witness the patriarchal condemnation of her sinful femininity that is perceived as a threat to men's spiritual ascent. Although she parades in a garb "not very different from a man's," male spectators are described as being in amazement at Pelagia's dashing clothing. For Betancourt, the figure is portrayed operating as male - seen by him "in the fallen state of the highly feminized sex worker" - even before the formal transition to monastic life where the process of confirming Pelagios' gender as male unfolds: "Pelagius's shamelessness seems to be demonstrated more by how he carried that scarf (as a man would) than

\footnotetext{
${ }^{33}$ Life of Pelagia 6, trans. Brock and Harvey, Holy Women, 43.

${ }^{34}$ Betancourt, Byzantine Intersectionality, 101.

${ }^{35}$ Life of Pelagia 39, trans. Brock and Harvey, Holy Women, 56.

${ }^{36}$ On Christian shame, see: Elizabeth A. Clark, "Sex, Shame, and Rhetoric: Engendering Early Christian Ethics," Journal of the American Academy of Religion 59 (1991): 221-45; Virginia Burrus, The Sex Lives of Saints: An Erotics of Ancient Hagiography (Philadelphia: University of Pennsylvania Press, 2004); and idem, Saving Shame: Martyrs, Saints, and Other Abject Subjects (Philadelphia: University of Pennsylvania Press, 2008).
} 
by his leaving his head uncovered as a sex worker." ${ }^{37}$ Symeon Metaphrastes suppresses this detail, mentioning only that when "the chorus of bishops saw her parading so shamelessly and impudently," everyone "condemned her lascivious appearance." ${ }^{38}$ These associations between the female gender and sexuality were so central that in depicting the sex worker's excessive pleasure the monastic author conveys a deep current of sexual anxiety that expresses itself in orthodox fashion as the perception of adultery.

On the basis of the earlier "masculine attire" of the sex worker, Betancourt asserts that Pelagios started his transition long before entering the lavra. However, later in the text, in her correspondence and in-person dialog with bishop Nonnos, Pelagia unmistakably self-identifies using feminine nouns, referring to herself as a "sinful woman" and a "she-wolf," and asking to make her a "bride of Christ" by means of baptism. ${ }^{39}$ The literary subject speaking here clearly identifies herself as a woman. I will thus use the female name, Pelagia, and employ she/her pronouns, that is to say, pronouns reflecting the identity the figure is displaying and the self-identified gender, but will acknowledge that Pelagios lived as a man from his transition until death, using the saint's preferred male name and he/him pronouns to recognize his expression of gender.

Pelagia's skin is said to be "dazzling as snow" and presented in opposition to her male-looking garb. In the Byzantines' gendered view on skin color, pale skin was associated with women's beauty and as such matched Pelagia's gender expression. As a sex worker she was consequently fair-complexioned and feminine in appearance. Wanting to emphasize Pelagia's white skin - and therefore her femininity - the narrator reveals his perception of the sex worker's gendered identity. With regard to the gendered color of skin, her white complexion anticipates and announces masculine darkness as articulated by Pelagios' skin color. In terms of intersectionality, racialization here works through gender.

Empowered as a sex worker, Pelagia is depicted as self-motivated to seek out the religious life in its extreme version to break completely the ties of patriarchal society. She shows devotion to ascetic life by discarding her female clothing and taking on the male attire of a recluse. In Christian hagiography, as Gillian Clark points out, the redeemed sex worker does not enter the marriage yet emulates the austerity of the ascetic whose non-sexual love

\footnotetext{
${ }^{37}$ Betancourt, Byzantine Intersectionality, 101.

${ }^{38}$ Life and Conduct of Saint Pelagia of Antioch 4, trans. Papaioannou, Christian Novels from the Menologion, 65.

${ }^{39}$ Life of Pelagia 20, 23, 26, trans. Brock and Harvey, Holy Women, 48, 50, 51.
} 
has salvaged her. ${ }^{40}$ Pelagia is converted by the ascetic bishop who induces her to go to the religious extreme embracing penitential practices and the solitary life of a hermit: ${ }^{41}$ she emancipates her slaves, donates her wealth to the church, and embarks on a life of self-mortification. Similarly to Maria who is rescued by the ascetic Abraham and conducted by a male authority to a life of austerity, ${ }^{42}$ Pelagia is redeemed and guided by Nonnos and eventually dons his own clothing. In this sense, Pelagia transforms her religious identity by means of transitioning in gender identity.

While attentive to the intersecting oppressions of gender, sexuality, and race, Betancourt's omission of class is telling. A blindness to class distinction is far from unique to this intersectionality scholar, as social class is rarely evoked in the literature on hagiography. However, excavating the female or trans identities of the late antique period requires simultaneous analysis of the position of the figure in the "class" topography of early Byzantium. Pelagia, after all, is described in the Life as a well-to-do woman of a high social class. Her beauty and clothing are not only markers of her sexual desirability but also of her elevated social status. While in the late Roman Empire most sex workers were slaves or freedwomen, Pelagia is certainly free by legal status. Moreover, she herself possesses slaves and a great fortune which she eventually bequeaths entirely to the church. ${ }^{43}$ The Life thereby equates a path of asceticism and sexual renouncement, for affluent women, with total renunciation of their wealth, "diverting it from the standard route of inheritance and thereby so disrupting the system of capital exchange within their class that eventually legislation was passed which prohibited such drainage of aristocratic holdings." ${ }^{44}$

In the second part of the narrative, Pelagia takes on the gender expression of a male monastic for the rest of life. The issue of salvation and

${ }^{40}$ Clark, Women in Late Antiquity, 31.

${ }^{41}$ Susanna Elm, "Marking the Self in Late Antiquity: Inscriptions, Baptism and the Conversion of Mimes," in Stigmata. Poetiken der Körperinschrift, eds. Bettine Menken and Barbara Vinken (Paderborn: Wilhelm Fink, 2004), 47-68, stresses the power of bishops to enact social conversion.

${ }^{42}$ Benedicta Ward, Harlots of the Desert: A Study of Repentance in Early Monastic Sources (Oxford: Mowbray, 1987), 85-91.

${ }^{43}$ A church steward is forbidden by Nonnos from accepting the wealth that Pelagia amassed, first qualified in her own words, then in the words of the bishop, "as a result of the sin of prostitution" (Life of Pelagia 37 and 39, trans. Brock and Harvey). For a discussion, see Daniel Caner, The Rich and the Pure: Philanthropy and the Making of Christian Society in Early Byzantium (Berkeley: University of California Press, 2021), 121.

${ }^{44}$ Elizabeth Castelli, "Virginity and Its Meaning for Women`s Sexuality in Early Christianity," Journal of Feminist Studies in Religion 2, no. 1 (1986): 83. 
its relation to the act of dressing in men's clothing is particularly stressed in the Life. Only when Pelagios passes away and is found in his cell, his fellow monks, while preparing to wash the corpse, realize his female identity. At no moment does the text explicitly demonstrate that Pelagios would come to perceive himself as male. However, upon taking the male name and presenting and passing as a eunuch within the male monastic community, the figure is shown to self-identify and live the rest of his life as a man.

How Pelagios' religious and gender identity is co-constituted from this point forward in the legend is revealing. The woman physically transforms the appearance of her body through dress in order to enter the lavra effectively passing as male-bodied eunuch. Yet Pelagios the monk conducts ascetic, body-altering practices, such as excessive fasting, clearly not out of fear of being revealed and expelled. Immured in a solitary cell on his own request, Pelagios through his penitential practices effaces the appearance of the sinful female body to the extent that it becomes unrecognizable. In the narrative that focuses on the transformation of the hermit's body into a masculine form, one catches a glimmer of a gender identity in concert with a spiritual transformation. Both Pelagios' gender and sexual identities are thus situated within the normative practices of asceticism and Christian worship. Jacob recounts:

...I failed to recognize her because she had lost those good looks I used to know; her astounding beauty had all faded away, her laughing and bright face that I had known had become ugly, her pretty eyes had become hollow and cavernous as the result of much fasting and the keeping of vigils. The joints of her holy bones, all fleshless, were visible beneath her skin through emaciation brought on by ascetic practices. Indeed the whole complexion of her body was coarse and dark like sackcloth, as the result of her strenuous penance. ${ }^{45}$

The story relates at length how Pelagios' body changed over those years, with his skin gaining a darker and coarser complexion. While Byzantines privileged whiteness in their descriptions of feminine beauty, dark skin was associated with the admirable strength of saintly heroes. But whether dark skin was seen as virtue or ugliness depended on one's gender and sexuality. Dark skin was considered unfeminine but praised as a sign of masculinity. Pelagia's bright face is seen as beautiful and feminine, whereas its darkening is perceived as ugly and unwomanly. Jacob does not recognize Pelagios as a woman because the latter appeared "dark like sackcloth." Indeed, what we

${ }^{45}$ Life of Pelagia 45, trans. Brock and Harvey, Holy Women, 60. 
are offered here is a description designed to simultaneously display an ascetic effacement of femininity and a masculine spiritual ascent. The text assumes a fundamental opposition between Pelagios' "fallen femininity and salvific masculinity." 46 Thus, part of affirming the male gender of the trans monk involved articulating a transformation in skin color and complexion.

At the same time, Pelagios contours his religious identity through asexuality. As a sex worker Pelagia has acted in a manner coded as adulterous, which is presented as related to female lust, metaphorically represented by the rich parade of bodies in her cortege. Through ascesis and salvific transition from femininity to masculinity, ${ }^{47}$ Pelagios, in his interiorized misogyny and full ideological conformity, seeks to perform penance for the previous sinful deeds: in Valerie Hotchkiss' words, the protagonist, has to "choose maleness to atone for sexual misconduct." ${ }^{48}$ The gender transition can thereby be viewed in conjunction with the sexual reversal of a former sex worker. It is not a question about Pelagia's "sexuality" per se, as it is represented through familiar tropes of beauty, or as we have come to understand the phenomenon of gender and sexual identity in terms of an expression or identification, but rather a question of the intersection of gender oppression and emancipation with religion.

Byzantine self-representation in religious literature can often be found in first-person accounts embedded in hagiography. The text presents the first-person perspective with the invented character of Pelagios speaking in his own voice. In this way the author creates the protagonist's self, with which the Christian reader can identify: "The holy Pelagia opened her mouth and spoke to me like a man. She said, "I think I have seen you somewhere, my brother...."49 Most frequently such first-person speeches manifest voices that one does not find in the Byzantine rhetorical tradition. The Life stages the self that speaks and reveals itself in action. The first-person discourse constructs self-representation, allowing Pelagios to presentan image of himself. This discursive performance of a literary subjectivity assigned to the character allows for exploration of the self in the hagiographic literature. It accounts for Christian forms of the self-expression of the "penitent" self. At the same time, the text also demonstrates how these performative subjects

\footnotetext{
${ }^{46}$ Betancourt, Byzantine Intersectionality, 101.

${ }^{47}$ Basil of Ancyra, On the True Purity of Virginity 51; ed. PG 30:772B-C, praises women becoming men via asceticism.

${ }^{48}$ Valerie Hotchkiss, Clothes Make the Man: Female Cross Dressing in Medieval Europe (New York: Garland, 1996), 21.

${ }^{49}$ Life of Pelagia 46, trans. Brock and Harvey, Holy Women, 60.
} 
would come to self-identify in terms of gender. Pelagios twice refers to Jacob as "my brother," unambiguously presenting himself as a male monk.

Betancourt insists on the subject's identification as a man negated by modern historiography, but, unlike Perpetua or Sarah, Pelagios makes no direct statement about his gender identity in his speech. The scholar claims that the text offers "praise for Pelagius's eventual life and death as a male eunuch." ${ }^{50}$ However, there are clear indications that at least the narrator, if not the author or a later copyist, wishes to remember Pelagios as a woman and not as a male eunuch. Jacob narrates their encounter on the Mount of Olives as follows:

As I approached his cell, I saw it had no door to it; on close examination I espied a small window in the wall in front of me. I knocked, and Pelagia, the handmaid of God, opened it. She was dressed in the habit of a venerable man. She came up and greeted me with great humility, clasping my hands and kissing them from within. She was overjoyed at my arrival, for the moment she saw me she recognized me. She was inside, and I outside.... ${ }^{51}$

Jacob's retrospective words point to his understanding of Pelagios' gender identity by referring to him in his description as a woman and using his female name and pronouns. With his identity posthumously revealed, Pelagios is buried and celebrated as a woman. As such he also enters the liturgical calendar of the church. Symeon Metaphrastes in his popular rewriting of the story makes the female identity of the ascetic even more pronounced.

The author of the Life clearly did not conceive of Pelagiosas a eunuch saint. To be sure, eunuch saints had existed since early Christianity, and their lives appeared throughout the Byzantine period. They were described in the set, canonical terminology of male saints complicated by a parallel one expected in portrayals of eunuchs. These gender-queer figures were problematic for Byzantine hagiographers: "eunuch saints' lives generally show their subjects receiving sanctity only indirectly, a reward divinely imposed on them rather than independently achieved." 52 In Byzantium, although full participants in the society and indisputably part of the Christian community, eunuchs rarely attained sanctity, and when they did, these figures were objects of no popular cults. ${ }^{53}$

\footnotetext{
${ }^{50}$ Betancourt, Byzantine Intersectionality, 101.

${ }^{51}$ Life of Pelagia 44, trans. Brock and Harvey, Holy Women, 59-60.

${ }^{52}$ Felix Szabo, "Non-Standard Masculinity and Sainthood in Niketas David's Life of Patriarch Ignatios," in Trans and Genderqueer Subjects in Medieval Hagiography, eds. Alicia Spencer-Hall and Blake Gutt (Amsterdam: Amsterdam University Press, 2021), 110.

${ }^{53}$ Ibidem. For a discussion on eunuchs and gender, see: Mathew Kuefler, The Manly Eunuch: Masculinity, Gender Ambiguity, and Christian Ideology in Late Antiquity (Chicago: University
} 
Betancourt presents eunuchs as belonging to a non-binary, gender-queer category, viewing Byzantine gender as a permeable social identity. ${ }^{54}$ In Byzantium, eunuchs ordinarily complicated the concept of masculinity. Being discursively rendered effeminate, they were occasionally excluded from the full spectrum of male-gendered privileges. To Betancourt, the interstitial condition of eunuchs who operated as gender-fluid figures, offered "a space for maneuvering around binary gender identities" in Byzantine society. ${ }^{55}$ But how far can an attribution of trans monks' and eunuchs' non-binariness be sustained in their historical context: does an assertion of non-binary identities of these figures allow for a more variegated form of manhood prevalent in Byzantium? In Byzantine literature, eunuchs - conceived as embodying masculinity, although a contingent one - are frequently portrayed as filling male-gendered roles: they are described as men and operate as such.

Intertextually, hagiographical treatment of Byzantine eunuch saints adds literary and historical context to Pelagios' representation as a eunuch. Introducing a trans figure, the Life offers a definition of masculinity more complicated than that of the gender binary in late antiquity. By locating eunuchs beyond these traditional categories, saint lives present "unparalleled models for integrating non-conforming masculinities within the otherwise strictly gendered norms of Christian hagiography." ${ }^{66}$ Pelagios is identified as a eunuch, and specifically a male one, but his description subverts long-standing tropes concerning eunuchs' expected behavior. Jacob narrates:

The whole of Jerusalem used to call her "the eunuch," and no one suspected anything else about her; nor did I notice anything about her that resembled the manner of a woman. I received a blessing from her as if from a male eunuch who was a renowned monk, a perfect and righteous disciple of Christ. ${ }^{57}$

By introducing this characterization of Pelagios, the Life presents a more fluid dimension of masculinity than is commonly encountered in Byzantine hagiography. By depicting his asceticism, the text constructs the trans masculinity of the protagonist as transcending the boundaries of a strict gender binary. Examining the Byzantine gender conception, Felix Szabo argues that Byzantine definitions of masculinity were more open and accessible to non-

of Chicago Press, 2001); Shaun Tougher, The Eunuch in Byzantine History and Society (London: Routledge, 2008).

${ }^{54}$ Betancourt, Byzantine Intersectionality, 119.

55 Ibidem.

${ }^{56}$ Szabo, "Non-Standard Masculinity," 109.

${ }^{57}$ Life of Pelagia 45, trans. Brock and Harvey, Holy Women, 60. 
men than historical and textual evidence may show. ${ }^{58}$ But what was the challenge of situating non-standard expressions of gender within hagiographical conventions? Neither fully female nor fully male, transmasculine figures of saints were associated with beardless eunuchs to fit into the broader hagiographical norms. That Pelagios could qualify to Byzantine audiences as a eunuch is witnessed by a number of later trans saints who infiltrate male monastic communities and are identified as eunuchs. Yet Pelagios, unlike Marinos who spent his entire life within a male monastery, is treated socially and grammatically as masculine rather briefly. Nonetheless, all the acts through which Pelagios' sainthood is manifested during his lifetime were performed by him as a man. The narrator recounts:

I, Jacob, spent every day wandering around to see the holy monasteries; I received blessing from them and heard how they would relate stories of the virtuous deeds of the monk Pelagios who lived the life of a recluse on the Mount of Olives, performing miracles. ${ }^{59}$

However, the revelation of Pelagios' identity after his death, which the religious authorities attempted to hide and which "immediately became known to the entire people," is also characterized as a wonder. Upon realization that "she was a woman," ${ }^{0}$ a bishop and local holy men who had come to anoint the ascetic body praised God for "hidden saints." Yet Pelagios is not a generic male saint. The circumstances of his life - a repentant entertainment star who dons male attire and embraces monastic obscurity - were hardly relatable to the general readership. If male saints ordinarily establish the requirements of righteous behavior for other men, women and eunuchs, who could aspire to sainthood only by subduing their unmanly nature, were appealing to broader audiences: to "all men and women who have repented or who shall repent." 61

If the Life was intended to be read as an example of salutary behavior, a panegyric to "her who was formerly an outcast, but who subsequently was chosen," what kind of model does the trans saint provide? With surviving evidence for a cult of St. Pelagia on the Mount of Olives in Jerusalem known from the late sixth century onwards, one can trace how the rules of sanctity apply to such marginalized and oppressed individuals. On the one hand, the figure was unambiguously sanctified as a woman as reflected not only in service books but also in pilgrims' accounts. The Piacenza pilgrim notes around 570: "on the mountain [of Olives] where the Lord ascended to the father,

\footnotetext{
${ }^{58}$ Szabo, "Non-Standard Masculinity," 111.

${ }^{59}$ Life of Pelagia 47, trans. Brock and Harvey, Holy Women, 60-61.

${ }^{60}$ Ibidem 50, 61.

${ }^{61}$ Ibidem 51, 62.
} 
we saw many things, including the cell where saint Pelagia was enclosed, and her body lies." ${ }^{2}$ On the other hand, an anonymous Latin guide from c. 1160 refers to the saint as male, recording "the Tomb of Saint Pelagius." ${ }^{63}$

Later Greek guides recount stories about the miraculous nature of her tomb, with hers being one of the two miracle shrines in the Holy Land: "In that place something marvellous occurs: for the marble holds people back until they make a complete confession. Thereupon, on being released, they embrace the tomb of the holy one." ${ }^{64}$ Latin pilgrim texts equally recount the miracle performed at Pelagia's tomb: "And near there is buried a holy woman, whose tomb no sinner can pass by or approach." 65

Both in her Life and cult, Pelagia is presented as a salvation model of the "repentant harlot" theme. Since the thirteenth century, the tomb of the Pelagia the Penitent had even been confused with that of another famous former sex worker, St. Mary of Egypt. ${ }^{66}$ However, another anonymous Latin text even mentions "a chapel of the Greeks, where the body of the blessed virgin Pelagia is," ${ }^{\prime 67}$ mistaking the harlot saint for a virgin. Yet another pilgrim's guide wrongly calls her a martyr: "Below is the chapel in which lies St. Pelagia (Pelage) the martyr." ${ }^{68}$ Overall, the figure of the trans saint emerges as significant evidence for the elasticity of gender and gender roles in early Byzantine Christianity.

The narrative representation of Pelagia does not concern itself exclusively with gender and sexuality: complications begin from conceptualizing these saints as sovereign, speaking "subjects." As Robert Mills highlights, when the saints speak, a speaking "I," a subject of power and agency, could be a site of competing contradictory discourses. ${ }^{69} \mathrm{He}$ asks if the voice of women saints can be satisfactorily represented by the modern hagiographic

62 "The Piacenza Pilgrim. Travels from Piacenza" 16, in: John Wilkinson, trans., Jerusalem Pilgrims Before the Crusades (Warminster: Aris \& Phillips 1977), 83.

${ }^{63}$ Seventh Guide 105, in Jerusalem Pilgrimage, 1099-1185, ed. John Wilkinson with Joyce Hill and William F. Ryan (London: Hakluyt Society, 1988), 236.

${ }^{64}$ Greek Anonymous I: A Partial Account of the Holy Places of Jerusalem (1253-54) 8, trans. Denys Pringle, Pilgrimage to Jerusalem and the Holy Land, 1187-1291 (London: Routledge, 2016), 190.

${ }^{65}$ Pilgrimages and Pardons of Acre (1258-63) 4, trans. Pringle, Pilgrimage, 231.

${ }^{66}$ These Are the Pilgrimages and Places of the Holy Land (Thirteenth Century) 4, trans. Pringle, Pilgrimage, 378.

${ }^{67}$ Anonymous IX (c.1229-39), trans. Pringle, Pilgrimage, 177.

${ }^{68}$ The Ways and Pilgrimages of the Holy Land (1244-65): Text A (1261-65) II, 14, trans. Pringle, Pilgrimage, 220-21.

${ }^{69}$ Robert Mills, "Can the Virgin Martyr Speak?" in: Medieval Virginities, eds. Anke Bernau, Ruth Evans and Sarah Salih (Toronto: University of Toronto Press, 2003), 207. 
scholar. In what voices do female saints speak - their own, those of their authors or readers? ${ }^{70}$ Yet the historical materialist approach to hagiographical texts as opposed to the rhetorical one explores the entanglement of material realities and discourse showing them as intimately entwined. Recovering late antique social identities with their own voices and agencies requires research to be historically situated to take into account the various ways in which these saintly figures were meaningful for their authors and audiences.

To conclude, late antique hagiographies were written to convey the ethical standards expected of its audiences through recording stories of exemplary figures. Authors of the vitae often wanted to transmit historical memory within the characteristic traits of the narrative of the hagiographic genre and held a specific religious agenda. Hagiography did not merely promote extreme asceticism; it was an ascetic practice in the late antique East as such. But if, by representing the saints, hagiographers strove to resemble them, what about trans saints and eunuchs? A tension exposed at the heart of Byzantine hagiography lies in celebration of what is ordinarily prohibited in canon law, namely, saintly women acting like men. Trans lives shattering gendered norms of Christian hagiography allow us a glimpse into the Byzantine imagination, but what the Life of Pelagia first offers us is fragments of evidence for gender-queer dimensions of historical social identities.

The relationship between the feminist critique which aims to recuperate women's agency and to center gender as a key point of female resistance and transgender theory which recovers historical trans subjectivities erased from the record are not those of incompatibility to each other. These two hagiographic readings are not irreconcilable. Crucially, the transgender theory lens does not exclude women as subjects but highlights other late antique lived subjectivities that have been negated or even assumed to have not existed.

Last but not least, despite its significance, social class, if not entirely neglected, is still rarely taken into account in the scholarship on hagiography in comparison to the related analytic vectors of gender and race. It is only by considering all of the dimensions of religion, gender, sexuality, ethnicity, and class within the structures of Byzantine society that we can understand the power relations of the period and their literary mediations. One's experiences of gender, sexuality, and race are conditioned by their relationship to a "class-relationship" that they are excluded from. They are best understood not as 'identity' issues, where class is only one identity among others, but by calling into question any assertion of a divide between "identity" and "class" and by distinguishing itself from reductionist invocations of the latter.

${ }^{70}$ Ibidem, 189. 